\title{
Özolguların Türkçeden Rusçaya Çevirisi Sorunu
}

\author{
The Problem of Realia's Translation from Turkish to Russian
}

Araştırma/Research

\section{Fatih YAPICI}

Dr. Öğr. Üyesi., Ankara Hacı Bayram Veli Üniversitesi, Edebiyat Fakültesi, Rus Dili ve Edebiyatı Bölümü, fatih.yapici@hbv.edu.tr, ORCID ID: orcid.org/0000-0003-3926-6984

\section{ÖZET}

Çeviri etkinliği, biçem, sözdizimi ve anlam parçacıklarından meydana gelmiş kaynak metni, anılan unsurların hedef dildeki eşdeğerleriyle yeniden oluşturmak olarak tanımlanabilir. Çeviri etkinliği basitçe bu şekilde tanımlansa da çeviriyi güçleştiren birçok unsur bulunmaktadır. Bunların başında da özolgular sayılabilir. Zira özolgular çevrilemez sözcük ya da sözcük grupları anlamına gelir. Özolguların çevrilemez olmasının temel nedeni bu sözcük ya da kavramların sadece bir kültürde bulunmasıdır. Çevirmenler, en başta karşılarına çıkan özolguları tespit etmekle yükümlüdürler. Ancak ondan sonra özolguların çevirisinde ne tür bir yol izleneceği konusunda kafa yorabilir ve çözümler ortaya koyabilirler. Kültüre has birimler olarak özolgulara en fazla rastlanan metinlerden biri masallardır. Türk masalları birçok farklı kültürden esintiler taşısalar da, Türk kültürünün en güzel taşıyıcılarından biri olarak kabul edilirler. Masallarda Türk kültürüne özgü günlük yaşam, inanışlar, birey toplum ilişkisi, örf ve adetler gibi pek çok alana ait kültürel unsurları gözlemlemek mümkündür. Masalların Türk kültüründeki yeri dikkate alınarak çalışmamızda Oğuz Tansel'e ait Al'ı ile Fırfıı adlı masallar kitabının Rusçaya çevirisi incelendi. Eserde geçen özolguların çevirmen tarafından hangi yöntemler izlenerek aktarıldığı araştırıldı. Özolguların sınıflandırılması konusunda Batı'da da sıkça başvurulan S.i. Vlahov ve S.P. Florin'in [Çeviride Çevrilemeyen] (Neperevodimoye $\checkmark$ perevode) adlı çalışmasından yararlanıldı. Karşılaştırmalı bir yöntem izlediğimiz çalışmamız sonucunda özolguların çevrisinde en çok yaklaşık anlam çevirisinin uygulandığını tespit ettik. Bununla birlikte diğer yöntemlerden de örnekler incelenmiştir.

Anahtar Sözcükler: özolgu, masal çevirisi, kültürdilbilim, eşdeğerlik

\section{ABSTRACT}

Translation activity can be defined as reconstructing the source text consisting of snippets of style, syntax and meaning with the equivalents of these elements in the target language. Although 
translation activity is simply defined in this way, there are many factors that make translation difficult. Among these factors, "realia" leads. Because realia means untranslatable words or phrases. The main reason why "realia" cannot be translated is that these words or concepts only exist in one culture. Primarily, translators are obliged to identify realia that they encounter. Only then they can ponder what kind of path to follow in the translation of realia and come up with solutions. One of the most common texts in which encountered realia as cultural units are fairy tales. Even though they have influences from many different cultures in the historical process, Turkish tales are among the most beautiful carriers of Turkish culture. In the tales, it is possible to observe cultural elements belonging to many areas such as daily life, beliefs, individual-society relationship, customs and traditions special to Turkish culture. In this respect, in our study, the Russian translation of the book of fairy tales named Al'lı ile Fırfırı by Oğuz Tansel was examined. The methods used by the translator to translate the realia in the work were investigated. In the classification of realia, S.I. Vlahov and S.P. Florin's work titled Untranslatable in Translation (Neperevodimoye $v$ perevode) was used. As a result of our study, in which we followed a comparative method, we determined that approximate translation of meaning is mostly applied in the translation of realias. However, samples from other methods were also examined.

Keywords: realia, fairy tale translation, linguistics of culture, equivalence

\section{Giriş}

Bu yazının amacı, çeviride eşdeğerlik açısından büyük sorun olan özolguların çevirisi konusunu Türkçeden Rusçaya çeviri örnekleri aracılığıyla araştırmaktır. Çalışmada Oğuz Tansel'in çevirmen Anastasiia Zherdieva ${ }^{1}$ (Anastasia Mihaylovna Jerdiyeva) tarafından Rusçaya çevrilen Al'lı ile Fırfırı (Al i Farfara) adlı eserinde geçen özolgular tespit edilmiş ve özolguların çevirisi ile ilgili ne tür yöntemler tercih edildiği araştırılmıştır. Kültüre has özelliği ile bir dilden başka dile aktarılması zor ya da olanaksız olan özolgular konusu hem çeviribilimcilerin hem de dilbilim ve kültürdilbilimcilerin ilgisini çekmektedir. Dil ve kültür arasındaki ilişkinin mahiyeti ya da karşılıklı etkileşimleri meselesi dil ve kültürle şu ya da bu şekilde uğraşan bütün araştırmacıların karşılarına çıkan ve cevabını aradıkları bir sorudur. Dilin toplumsal gerçekliği yansıttığı, kültürün büyük oranda dil aracılığıyla aktarıldığı gerçeğini dikkate aldığımızda soruna yanıt bulmaya yaklaştığımızı düşünebiliriz. Yani dil hem kültürel unsur hem de kültürün gelecek nesillere iletilmesini sağlayan araç olması bakımından çok yönlü bir yapıya sahiptir. Belli bir kültürü aktarırken dil kodlardan faydalanır. Adı geçen kodlardan bazıları tamamen somut bir dile ve kültüre ait olurlar ki söz konusu önemli leksik ögeler özolgulardır. Özolgu (realia, Latince 'somut', 'reel' anlamındaki orta cins realis,-e sözcüğünün çoğul çekimlenmiş halidir, yaşam

\footnotetext{
1 Kültür bilimci, halkbilimci ve çevirmen. Lisans, yüksek lisans ve doktorasını Kültür Bilim alanında V.i.Vernadskogo Tavriyskıy Milli Üniversitesi'nde tamamladı. 2012-2015 yıllarında Ortadoğu Teknik Üniversitesi'nde Sosyoloji Bolümü Sosyal Antropoloji Anabilim Dalı'nda doktora sonrası araştırma programına katıldı. Çevirmenin Türkiye'de ve Kırım'da yayınlanan birer kitabı ve Rusça yayınlanan çeviri kitapları şunlardır: Zherdieva A. (2019). Kırım efsaneleri. Ankara: Son Çağ Kültür, (Türkçe), Tansel O. (2018). Al'ı ile Fırfırı. Simferopol: Tarpan, (Çeviri ve masalların analizi: A.Zherdieva). (Rusça), Zherdieva A. (2017). Dünya kültürünün bir parçası olarak Kırım efsaneleri. Simferopol: Tavrida, (Rusça), Zherdieva A. (2017). Anadolu masalları. Simferopol: Tarpan, (Hazırlayan, çeviren: A. Zherdieva). (Rusça), Zherdieva A. (2015). Türk menkıbeleri. Simferopol: Tarpan. (Hazırlayan, çeviren: A. Zherdieva), (Rusça), Zherdieva A. (2014). Türk efsaneleri. Simferopol: Tarpan, (Hazırlayan, çeviren: A. Zherdieva), (Rusça).
} 
kavramıyla sıkı sıkıya bağlı olup 'nesne', 'eşya' anlamlarına gelmektedir). Mosiyenko, $(2014$, s. 89) kavramı, çeviribilim terimi olarak metinde çevrilemeyen unsurları anlatır. S.i. Vlahov ve S.P. Florin'e göre özolgu, yaşam ve kültürün, tarihi dönemin ve sosyal yapının, devlet sisteminin ve folklorun unsurlarını, yani belirli bir halkın ya da ülkenin, başka halk veya ülkelere yabancı olan özgün yönlerini ifade eden sözler için kullanılır (Vlahov \& Florin, 1980, s. VI). Vlahov ve Florin'in ortaya koyduğu metinde çevrilemeyen özolgulardan önce çeviride eşdeğerlik konusu ve konuyla ilgili Rus dilbilimsel çeviribilim ekolünün en önemli kuramcılarından Komissarov'un kuramından bahsetmek faydalı olacaktır.

\section{Eşdeğerlik Sorunu ve Komissarov'un Kuramı}

Eşdeğerlik (En. Equivalence, Rus. Ekvivalentnost) sorunu, çeviribilim çalışmalarında ve çeviri teorisinde en temel sorunlardan birisidir. Batı'da çeviribilimin ortaya çıkmasından sonra konuyla ilgili ilk görüşler Jakobson ve Nida'nın yaptığı çalışmalarla ortaya çıkmış ve halen günümüzde tartışılmaya devam edilmektedir. Sözcüğü sözcüğüne çeviriden anlam çevirisine, dilbilimsel eşdeğerlikten (Jakobson, Nida) kültürel eşdeğerliğe ( $P$. Newmark) ya da metin düzeyindeki eşdeğerliğe (J. C. Catford), hatta eşdeğerliğin çeviribilimin önemli bir sorunu olmadığını düşünen değişik görüşler (Mary Snell-Hornby) ve kuramlara kadar farklı yaklaşımlar ortaya konulduğu gözlemlenmektedir (Karavin, 2016, s. 126136). Sovyet Rusya'da ise 20. yüzyılda çeviribilim çalışmaları dilbilgisel çeviribilim kuramları temelinde başlamış ve bu alanda yoğunlaşmıştır. Çeviri sırasında uyulabilecek belirli dilsel kuralların varlığından ilk bahsedenlerden birisi 1950'li yıllarda Rus dilbilimsel çeviri teorisinin kurucusu Yakov İosifoviç Retsker'dir. Retsker kuramını, kaynak ve hedef dildeki sabit dilbilgisi eşdeğerliklerin ortaya konulması üzere inşa eder. Dilbilgisel kuralların sabit olması, çeviri sırasında eşdeğerlik konusundaki seçimlerin aslında rastgele değil, belirli kurallar çerçevesinde yapıldığını göstermektedir (Komissarov, 1990, s. 20). Çeviride dilbilgisel yaklaşımın, Batı'da ve Rusya'da birbirine yakın zamanlarda, farklı bilim insanlarınca dile getirildiği görülmektedir.

Rusya'da dilbilimsel çeviri kuramının en önemli temsilcilerinden Vilen Naumoviç Komissarov (1924-2005), yarım yüzyıl boyunca sürdürdüğü Moskova Devlet Dilbilim Üniversitesi'ndeki yöneticiliği sırasında çeviri kuramı üzerine birçok değerli çalışma ortaya koymuş önemli bir bilim insanıdır. Ünlü bilim insanına göre çeviri için sadece iki dili bilmek yeterli değildir, iki dili çeviri için bilmek gerekmektedir. Bu, bir dilin leksik parçacıklarının diğerine geçiş kural ve şartlarını bilmekle ilişkilidir (Komissarov, 1973, s. 7). Komissarov'un bu görüşünden yola çıkarak, çeviribilimin amacı, bu kuralları ortaya çıkararak çevirmenlere yol göstermektir denilebilir.

Eşdeğerlik konusunda birçok çalışması olan Komissarov, Rus çeviribilim araştırmalarına getirdiği özgün kuramı ile tanınır. Belli başlı çeviri kuramlarını inceleyen Komissarov, kendi kuramını ortaya sürer: Eşdeğerlik Düzeyleri Kuramı (Teoriya urovney ekvivalentnosti). Bu kuram, eşdeğerliğin kaynak dil ve erek dildeki değişik anlam düzeylerindeki benzerlikler ile sağlanabileceği varsayımına dayanır. Kuramın temelinde, kaynak dildeki metnin erek dilin okuyucusuna aktarılırken metnin içeriğinin, içerdiği bilginin türüne göre bir takım düzeylere ayrılması yatar (Komissarov, 1973, ss. 61-62). 
Eşdeğerlik Düzeyleri Kuramı́nın özü, dil sistemlerindeki ve dillerin metin üretme biçimlerindeki birtakım farklılıklar nedeniyle kaynak dildeki içeriğin tam anlamıyla aktarılamadığı gerçeğidir. Bu yüzden çeviride eşdeğerlik, temelde orijinal metinde bulunan anlam parçacıklarının korunup (ya da korunamadan) aktarılabilmesidir. Çeviri sırasında eşdeğerliğin sağlanması için içeriğin hangi bölümünün aktarıldığına bağlı olarak farklı eşdeğerlik düzeyleri ortaya çıkmaktadır. Her eşdeğerlik düzeyinde çeviri diller arası iletişimi sağlayabilmektedir (Komissarov, 1990, s. 51). Bununla birlikte eşdeğerliğin en ileri düzeyde gerçekleşebilmesi için, söz konusu eşdeğerlik düzeylerinden olabildiğince fazlasının sağlanması gerekmektedir. Dilsel göstergelerin ifade ve anlam yönleri olduğunu dikkate alan Komissarov, bu göstergelerin anlamsal içeriklerini çeşitli düzeylere ayırmaktadır. Çeviri sırasında bu düzeylerden herhangi birinin sağlanması, çeviriyi eşdeğer çeviri yapar. Komissarov'a göre adı geçen eşdeğerlik düzeyleri şunlardır:

1) Dilsel gösterge düzeyi (uroven yazıkovıh znakov; slov)

2) Sözce düzeyi (uroven viskazıvaniya)

3) Bildiri düzeyi (uroven soobşeniya)

4) Durumun tasviri düzeyi (uroven opisaniya situatsii)

5) İletişimin amaç düzeyi (uroven tseli kommunikatsii) (Komissarov, 1990, s. 76).

Çevirmen, Komissarov'un kuramında sıralanan eşdeğerlik düzeylerinin hepsini ya da bir kısmını aktarabilir. En mükemmel çeviri bu düzeylerin ne kadarının ne seviyede doğru şekilde aktarıldığı ile alakalıdır. Çevirmenlerin çevirisi sırasında dikkat etmesi gereken söz konusu düzeyler konusundaki yaklaşımı, çevirinin başarısını belirler. Amaç düzeyinin aktarılmasının eşdeğerliğin en alt seviyesi olduğunu belirtmek, Komissarov'un kuramını açıklamak açısından anlamlı olacaktır. Komissarov birçok çalışmasında, söz konusu düzeyleri detaylarıyla açıklamakta ve İngilizce-Rusça çeviri örnekleriyle de desteklemektedir.

Yukarıda sıralanan düzeylerden beşincisi içeriğin barındırdığı genel anlamı, dördüncüsü bu genel anlamın aktarıldığı iletişim ortamını ifade eder. İlk üç düzey ise bu iletişim ortamının hangi dilsel ifadelerle gösterildiğini anlatan düzeylerdir. Bu bakımdan son düzey olan iletişim amacı düzeyinde sadece ileti ile anlatılmak istenen aktarılmaktadır. Beşinci düzey, çeviride eşdeğerliğin en az seviyede karşılandığı, diğer yandan çeviride asıl aktarılması gereken amacın bir şekilde ifade edildiği düzeydir. Yan anlamların aktarılması, konuşan kişinin duygu ve hislerinin aktarılması, şiirsel gücün ifadesi bu düzeyde aktarılan içeriklerdendir. Bu tür aktarımda, orijinalde anlatılmak istenen ve bunun anlatılma yöntemi çeviride aynı biçimde yer bulamaz. Rusçadaki $\mathrm{OH}_{H}$ снял трубку-On snyal trubku (sözcüğü sözcüğüne 'O boruyu aldı') ifadesi Türkçemize $O$ telefona cevap verdi ya da $O$ ahizeyi kaldırdı olarak aktarılır. Her iki çeviri de amacı aktarmakla birlikte, orijinal cümleyle sözcük noktasında eşdeğer değildir.

Komissarov'un çalışmasında eşdeğerliğin çok aşamalı bir kavram olduğunu görmekteyiz. Sözcükten anlama ve anlamdan sözcüğe doğru ilerleyen eşdeğerlik katmanlarını çevirmenlerin çeviri sırasında en üst seviyeden karşılayabilmeleri, en başta bir kültür aktarımı olan çeviri etkinliğinde olasılığı zor görünmektedir. Zira her kültür 
kendi değerler dünyasını kurmakta, insanoğlu algıladığı dünyayı kendi zihninde akıl ile işlemektedir. Bunun sonucunda kültürel farklılıklar ortaya çıkmakta, toplumların dünya görüşleri meydana gelmektedir. Bogdanoviç'e göre kültürdilbilimin temel kavramı olarak kültür, dünya görüşünü, insan davranışının temelinde yatan ahlak normlarını, dünyayı anlamlandırma biçimlerini, sanat eserleriyle manevi ve maddi değerleri kapsamaktadır (Bogdanoviç, 2004, s. 65). Dolayısıyla söz konusu unsurlar kültürden kültüre değişiklik göstermekte, hatta her kültürde eşit biçimde bulunmamaktadır. İşte bu diğer kültürlerde karşılığı bulunmayan kavram ve değerlere özolgu denmektedir. Özolgular değişik adlar altında ve farklı bilim adamlarınca tasvir edilmiştir. Örneğin P. Newmark çevirisi zor olan bu kültürel özellikleri çevre, kamu hayatı, sosyal yaşam, kişisel yaşam, gelenek-görenek, sosyal etkinlikler ve kişisel merak ve tutkular olarak sınıflandırmıştır (Morsy, 2019, s. 2603). Biz bu çalışmamızda Bulgar çevirmenler Vlahov ve Florin'in [Çeviride Çevrilemeyen] (Neperevodimoye v perevode) adlı eserlerinde özolgular ile ilgili tespit ve sınıflandırmaları ile özolguların çevirisi konusundaki önerilerini inceledik.

\section{3. Özolgu Kavramı ve Özolguların SınıflandırıIması}

Özolgu terimi ülkemizde ilk kez Olena Kozan’ın editörlüğünde yayınlanan Kültürdilbilim adlı kitapta yer alan L.V. Mosiyenko'nun “Kültürdilbilimde Özolguların Sınıflandırması Sorunu" (Mosiyenko, 2014, s. 87) adlı makalenin çevirisinde kullanılmıştır. Ayrıca Dede Korkut Kitabında Özolgular adlı bildirisinde Erdoğan Boz ve Manas Ansiklopedisi'nde Özolgu Ifadeleri adlı makalede de Cüneyt Akın adı geçen eserlerde özolguları Mosiyenko'nun makalesinden hareketle incelemişlerdir. Çeviribilim açısından özolgular Vlahov ve Florin tarafından ilk kez detaylı bir şekilde incelenmiş ve Batı'daki çalışmalar onların eserine göre konuyu ele almışlardır. Bu açıdan biz de çalışmamızda Vlahov ve Florin'in ortaya koyduğu özolgu sınıflandırmasını inceleyerek ona göre Türkçe özolguların Rusçaya çevirisini ele aldık.

Burada özolgu terimini kullanmamızın nedeni ise çalışmamızda incelediğimiz Vlahov ve Florin'in eserlerinde Rusça realia olarak adlandırdıkları kavramın diğer çevrilemez sözcüklerden farklı olduğunu düşünmelerinden kaynaklanmaktadır. Vlahov ve Florin'e göre Rusya'da çeviribilim alanında yapılan çalışmalarda söz konusu sözcüklerle ilgili olarak kullanılan birçok terim vardır. Ancak bu terimler realia yani özolgu kavramını tam olarak karşılamamaktadır. Örneğin yerel sözcükler kavramı yerel nesneleri karşılarken milli özelliklerin sadece küçük bir kısmını ifade edebilmektedir. Diğer yandan egzotik sözcük hazinesi ise terimin anlamını daraltmaktadır (Vlahov \& Florin, 1980, s. 37). Vlahov ve Florin boşluk, yeni sözcük türetme, yabancı sözcükler gibi çeviribilim kavramlarının da özolgu kavramını karşılamadıklarını düşünürler. Ayrıca çevrilemeyen sözcükler anlamında eşdeğeri olmayan sözcükler (bezekvivalentnıye slova) terimi de, üzerinde tam bir uzlaşı olmayan terim olması dolayısıyla tercih edilmez. Onlara göre bu terim bazen özolgular, bazen geniş anlamda yabancı kültürde ve dilde olmayan sözcükler, dar anlamda Sovyet yaşamına ait sözcükler ve son olarak da başka dillere çevrilemeyen sözcükler anlamında kullanıldığını ifade ederler (Vlaho \& Florin, 1980, s. 41). Vlahov ve Florin, yukarıda sayılan nedenlerle çalışmalarında realia terimini kullandıklarından biz de burada henüz yeni olmakla birlikte realia kavramını 
karşılayabileceğini düşündüğümüz özolgu terimini kullandık. Tabii ki terimin uygun olup olmadığı konusunda son takdiri okuyucuya bırakıyoruz.

Bizim tercih ettiğimiz özolgu teriminin karşılığı olarak realia kavramının dilbilim ve çeviribilimde kazandığı anlamlar Rus bilim insanlarının da ilgisini çekmektedir. Örneğin N. A. Fenenko "Realia Teriminin Dilbilimsel Konumu" adlı makalesinde terimin Vlahov ve Florin tarafından yapılan yorumuna değinmiş, onların realia terimi ile göndergeyi değil bizzat sözcüğü ifade ettiklerini belirtmiştir. Ayrıca çalışmada terimin felsefe, kültürdilbilim ve dilbilimdeki yorumları açıklanmıştır. N. A. Fenenko, Rusya'dakinin aksine Fransız dilbilim ve çeviribilim yaklaşımlarının realia kavramının arkasında gönderge kavramını gördüklerini, ilgili sözcükleri ise yerel sözcük, kültürel değere sahip terim gibi kavramlarla ifade ettiklerini belirtmektedir (Fenenko, 2007, ss. 5-9).

Yukarıda da belirttiğimiz gibi Vlahov ve Florin'e göre özolgu, yaşam ve kültürün, tarihi dönemin ve sosyal yapının, devlet sisteminin ve folklorun unsurlarını, yani belirli bir halkın ya da ülkenin, başka halk veya ülkelere yabancı olan özgün yönlerini ifade eden sözler için kullanılır (Vlahov \& Florin, 1980, s. VI). Vaysburd, Rossels ve Barhudarov gibi birçok Rus bilim insanı konuya temelde aynı açıdan yaklaşmaktadır (Mosiyenko, 2014, s. 89). Buna göre özolguların ayırt edici özelliği, bu sözcük ya da olguların bir milletin dilinde ve yaşamında var olup başka halklarda mevcut olmamasıdır.

Vlahov ve Florin çalışmalarında özolguları nesne, yer, zaman ve çeviri açısından olmak üzere dört sınıfta incelerken bunlar da alt kategorilere ayrılırlar. Nesne sınıfının alt kategorilerinde coğrafi, etnografik, toplumsal ve siyasi özolgular bulunur. Aşağıdaki sınıflandırmalarda verilen örnekler Vlahov ve Florin'in çalışmasından alınmıştır.

1. Nesneye göre sınıflandırma

1.1. Coğrafi özolgular,

1.1.1. Fiziki coğrafyaya ait objelerin adıyla birlikte meteoroloji (step, fiyort, tornado, sırt ${ }^{2}$, vadi $^{3}$ ),

1.1.2. Insan faaliyetleri ile ilişkili coğrafi objelerin adları (polder, gliba ${ }^{4}, \operatorname{arık}^{5}$ ),

1.1.3. Endemik türlerin adları (kivi, yeti, kar adam) bulunmaktadır.

Nesneye göre sınıflandırılan özolguların diğeri etnografik özolgular olarak karşımıza çıkmaktadır.

1.2. Etnografik özolgular,

\footnotetext{
2 Türkçeden sırt (Y.N.)

${ }^{3}$ Arapçadan (Y.N.)

${ }_{4}$ Suda yüzen buz parçası ya da kıyıda balık tutmak için çitle çevrili yer (https://ru.wiktionary.org/wiki/\%D0\%BA\%D1\%80\%D0\%B8\%D0\%B3\%D0\%B0)

${ }^{5}$ Türkçeden ark, hark (Y.N.)
} 
1.2.1. Yaşam: Yiyecekler, içecekler vs. (şi ${ }^{6}$, spagetti, kımız...); yaşamsal kurumlar (taverna, bistro, hamam, sauna...); ayakkabı ve başı örtmede kullanılanlar da dâhil giyecekler (burnus, kimono, ferace...); süs eşyaları ve kıyafetler (kokoşnik ${ }^{7}$ fibula...); ev, mobilya, kapkacak ve diğer eşyalar (yurta ${ }^{8}$, iglo...); ulaşım (araçlar ve sürücüler), (troyka, gondolier...); diğerleri (sakva ${ }^{9}$, dinlenme evi (dom otdıha $\left.{ }^{10}\right)$.

1.2.2. İş: Çalışan insanlar (öncü işçi (peredovik) ${ }^{11}$, fellah, tellak); iş aletleri (bumerang, ketmen); iş kurumları (işletmeler vd. dâhil) (kolhoz, agrokompleks, esnaf).

1.2.3. Sanat ve kültür: Müzik ve danslar (lezginka, tarantella); müzik aletleri (balalayka, kaval, banjo); folklor (kaside, saga, gazel); tiyatro (commedia dell'arte, misteri, no); diğer sanatlar ve sanatsal nesneler (ikebana, peliken); icracıları (Minnesänger, trubador, âşık); gelenekler, ayinler (vendetta, tya-no-no çay seremonisi, tamada); bayramlar, oyunlar (1 Mayıs, holi, paskalya, kriket, pitcher); mitoloji (Elf, kum adam, uçan halı, Trol); kültler; önderler ve taraftarları (Lama, hoca, mormonlar, derviş, hac), kült bina ve eşyalar (mescit, sinagog, haç, mani); takvim (Vaiśākha, pastırma yazı).

1.2.4. Etnik objeler: etnonimler (Bantu, Hutsullar, Kazak); lakaplar (genelde gülünç ve gücendirici) (hohol, gringo); kişilerin yaşadıkları yere göre adlandırılması (Taraskonlu, Gabrovalı).

1.2.5. Ölçü ve para birimleri: Ölçü birimleri ( $\operatorname{arşın,~yarda,~pud~}{ }^{12}$ ); para birimleri (lira, kuruş, ruble); ölçü ve para birimlerinin halk dilinde söylenişleri.

\subsection{Toplumsal ve politik özolgular.}

1.3.1. İdari-bölgesel düzen: İdari-bölgesel birimler (guberniya ${ }^{13}$, oblast ${ }^{14}$, vilayet, kaza, kanton); yerleşim birimler, (avul, mahalle, bidonville); yerleşim birimlerinin detayları (arrondissement, kreml ${ }^{15}$, çarşı).

1.3.2. Kurumlar ve yöneticiler (meclis, duma, ispolkom) ${ }^{16}$, han, çar, şah, firavun).

1.3.3. Toplumsal-politik hayat: politik faaliyetler ve politikacılar (Bolşevik, Troçkici, ku klux klan, presbiteryen); vatansever ve toplumsal hareketler ve detayları (slavseverler

\footnotetext{
${ }^{6}$ Lahana çorbası (Gültek, 2004, s. 1929).

${ }^{7}$ Eski Rusya'da kadınların başlarına giydikleri giysi ya da başlık (Gültek, 2004, s. 568).

${ }^{8}$ Göçebe çadırı, çadırt, yurt (Gültek, 2004, s. 1950).

${ }_{9}^{9}$ Süvari tahıl çuvalı. (http://feb-web.ru/feb/mas/mas-abc/18/ma401407.htm?cmd=0\&istext=1)

${ }^{10}$ Sovyetler Birliğinde işçilerin dinlenmesi için kurulan, çoğunlukla ücretsiz olan tatil yerleri.

Sanatoryumlardan farkı, buralara sağlıklı insanların gelmesidir

(https://dic.academic.ru/dic.nsf/bse/85351/\%D0\%94\%D0\%BE\%D0\%BC).

${ }^{11}$ Sovyetler Birliğinde işinde iyi olan, diğerlerinin önüne geçen işçiler için söylenir. Öncü işçi (Gültek, 2004, s. 1073).

12 Eskiden Ruslarda 16,38 kilogramlık ağırlık birimi (Gültek, 2004, s. 1346).

13 il, vilayet (Gültek, 2004, s. 276).

${ }^{14}$ Bölge, mıntıka (Gültek, 2004, s. 893).

${ }^{15}$ Kale, hisar (Gültek, 2004, s. 610).

16 İcra komitesi (Gültek, 2004, s. 511).
} 
(slavyanofilı) ${ }^{17}$ partizan, Kızılay); sosyal olay ve hareketler (Publicity, lobi, lobici, hippi); rütbe, derece, unvan, hitap (doktor, bakalorya, prens, baron, lord, sör, madam); kurumlar (evlendirme dairesi, sanat ve kültür komitesi,); eğitim ve kültür kurumları (kolej, lise, medrese); sınıflar ve kastlar (onların üyeleri) (tüccar, soylu, brahman, üçüncü sınıf, samuray, mujik ${ }^{18}$ ); sınıf işaret ve sembolleri (beş köşeli yıldız, fleur de lis ${ }^{19}$, hilal).

\subsection{Askeri özolgular.}

1.4.1. Askeri birlikler (lejyon, falanj ${ }^{20}$ ); silahlar (arbalet ${ }^{21}$, yatağan (kılıcı), finka ${ }^{22}$, hançer); askeri üniforma (miğfer, kolçuga) ${ }^{23}$; askerler (ve komutanlar) (ataman, Sebastokratōr, yeniçeri, başıbozuk).

[Çeviride Çevrilemeyen] adlı eserde nesneye göre sınıflandırma burada son bulmaktadır. Yazarlar bundan sonra anlatılacak olan yere göre ve zaman göre yapılan sınıflandırmanın aynı özolgularla ilişkili olduğunu, sadece farklı bakış açısından incelendiklerini belirtirler (Vlahov \& Florin, 1980, s. 56). Yere göre sınıflandırma görecelidir. Çünkü Vlahov ve Florin'e göre burada etkili olan kati bir şekilde yer değil belirtilen nesnenin ya da onun göndergesinin ait olduğu yer (ülke, halk, şehir, kabile) ve çeviri yapılan dil çiftleridir (erek ve hedef diller) (Vlahov \& Florin, 1980, s. 57). Dolayısıyla çalışmada dil dışı değil dilsel etkenlere değinilmektedir. Sonuçta söz konusu özolgular karşımıza iki dil arasında gerçekleşen çeviri etkinliği sırasında çıkarlar. Bu açıdan Vlahov ve Florin özolguların tek dil düzleminde (kültüre has özolgular, yabancı özolgular) ve iki dil düzleminde (iç özolgular, dış özolgular) olarak incelenmesi gerektiğini belirtirler (Vlahov \& Florin, 1980, s. 57). Bu durumu aşağıdaki şemayla şu şekilde gösterirler:
A. Tek dili düzleminde
B. İki dil düzleminde
1. Kültüre has özolgular
1. İç özolgular
a. Milli
2. Dış Özolgular
b. Yerel
c. Mikroyerel
2.Yabancı Özolgular
a. Uluslararası
b. Bölgesel (Vlahov \& Florin, 1980, s. 57).

\footnotetext{
17 Slavseverlik (Slavyanofilstvo), I. Petro'nun Avrupalı bir Rusya kurma çabalarına karşı reaksiyon olarak ortaya çıkan, Rusların Avrupa değerleriyle değil ortodoksluk ve sosyal birlik gibi milli değerlerle ilerlemesi gerektiğini düşünen, Rusya dışındaki Slavlar için ise Panslavizm düşüncesini ortaya koyarak siyasi bir akım halin alan fikir akımıdır (Kurat, 1999, ss. 332-334).

18 1.Köylü, mujik, 2. Erkek, herif, adam (Gültek, 2004, s. 736).

${ }_{19}$ Zambak çiçeği (http://www.gazetebilkent.com/fleur-de-lis-neyin-sembolu/)

${ }^{20}$ Eski Yunanistan'da mızraklı alay (Gültek, 2004, s. 1817).

${ }^{21}$ Kundaklı, tetikli yay (Türkçe Sözlük, 2011, s. 147)

22 Fin kaması, bıçak, hançer (Gültek, 2004, s. 1827).

${ }^{23}$ Yelme (Demir ya da çelik halkacıklardan yapılmış, önden açılır zırh) (Gültek, 2004, s. 575).
} 
Kültüre has özolgular, bir dilin özbeöz kendine ait özolguları kastedilmektedir. Vlahov ve Florin Rusçadan semaver ${ }^{24}$, boyarin ${ }^{25}$ (eski Rusya'da kökten soylu, sonradan saray çevresine katılanlar değil), Sovyet (şura), Ingilizceden heath, ale, Almancadan Heurige sözcüklerini örnek olarak gösterirler. Diğer yandan bu noktada bir ayrıntıya da dikkat çekilen çalışmada bazı dillerin kendine has özolgular arasına giren sözcüklerin alıntı sözcükler olabildiği ifade edilmektedir. Örneğin Bulgarcada Türkçe ve Farsçadan giren birçok sözcük olduğu bu türden özolgular olarak kabul edilmektedir (Vlahov \& Florin, 1980, s. 58).

Çalışmada yabancı özolguların ya alıntı sözcükler, ya taklitler yani yabancı adlandırmaların sözcüğü sözcüğüne yapılan çevirileri ya da sözcüklerin transkripsiyonu sonucu bir dile yerleşen sözcükler olduğu ifade edilir. Örneğin Amerikan İngilizcesinden Rusçaya ve birçok dile geçen business (biznes) ve Rusçadan çoğu Batı dillerine yerleşen sputnik (ahbap, yol arkadaşı, uydu, peyk ${ }^{26}$ ) sözcükleri yabancı özolgulardır (Vlahov \& Florin, 1980, s. 58).

İki dil düzleminde olan özolgular iç ve dış özolgular olarak ikiye ayrılmıştır. Bu sınıflandırma tamamen dil çiftleri arası çeviri ile ilişkilidir. Vlahov ve Florin, söz konusu özolgular için fiyort örneğini vermektedirler. Fiyort özolgusu örneğin Türkçe ve Rusça dil çiftleri ya da Almanca Rusça dil çiftleri arasında gerçekleşen çeviri ediminde adı geçen diller için dış özolgu olarak kabul edilir. Diğer yandan Norveççe ve Türkçe ya da İngilizce Norveççe dil çiftleri arasında yapılan çevirilerde ise aynı özolgu iç özolgu olarak görülür (Vlahov \& Florin, 1980, s. 58). Anlaşılacağı üzere iç ve dış özolgular ayrımı tamamen çeviri eylemi ile bağlantılıdır ve çeviri ediminin gerçekleştiği dillere göre değişim göstermektedir.

Vlahov ve Florin son olarak özolguları zamana göre sınıflandırmaktadır. Zamana göre sınıflandırmanın en genel anlamda çağdaş ve tarihi özolgular olarak ikiye ayrılabileceği belirtilen çalışmada zaman faktörüne bağlı olarak oluşan şu sorunların incelenmesi gerektiği düşünülmektedir: 1. Özolguların nesne ve zaman bakımından ilişkisi, 2. Mekan ve zaman bakımından ilişkisi, 3. Yabancı özolguların dile girmesi, 4. Bu şekilde bir dile özolguların yerleşmesinde en temel yollardan birinin edebi metinler olması ve 5. Özolguların bilindik olması ya da olmaması, yabancı bir dile yerleşmesi sorunu (Vlahov \& Florin, 1980, s. 65).

Illk sorun incelendiğinde özolgularda nesne zaman ilişkisi onların zaman düzleminde çeşitli boyutlara geçmeleriyle ilişkili olduğu görülür. Vlahov ve Florin'in konuyla ilgili verdikleri örneklere bakıldığında mesele daha iyi anlaşılmaktadır. Vlahov ve Florin, zaman içinde bazı özolguların güncelliğini yitirerek tarih alanına geçtiklerini ya da tam tersi bir durum ortaya çıkabildiğini belirtirler. Rusçadaki samolyot sözcüğü uçak anlamına gelmektedir. Sözcüğün Türkçemizde tam karşılığı kendiuçandır. Bu sözcük bir

\footnotetext{
${ }^{24}$ Rusça kendi (sam) ve kaynamak (varit) sözcüklerinlerinin bir araya gelmesiyle semaver (samovar) sözcüğü su kaynatmaya yarayan alet anlamında oluşmuştur (https://www.etimolojiturkce.com/arama/semaver).

${ }^{25}$ Krılov ve Şanski'nin etimoloji sözlüğünde sözcüğün kökeni olarak Rusça boy yani savaş sözcüğü gösterilse de Fasmer buna ilave olarak sözcüğün kökeninin Türkçedeki bay yani bey sözcüğünden gelebileceği fikrini de dikkate alır (https://gufo.me/dict/vasmer/\%D0\%B1\%D0\%BE\%D1\%8F\%D1\%80\%D0\%B8\%D0\%BD).

${ }^{26}$ (Gültek, 2004, s 1615).
} 
masal özolgusu iken (uçan halı için kullanılır) uçma aracı anlamına gelerek terimleşmiştir. Şu anda sözcük günlük konuşma dili hazinesine dâhil olmuştur (Vlahov \& Florin, 1980, s. 66). Sorun, bir dilin söz varlığında zaman içerisinde tarihi, kültürel, ekonomik vd. nedenlerle meydana gelen değişimlerle ilişkilidir. Bilindiği üzere toplumsal yapıdaki büyük ölçekli değişimler dilde hemen karşılık bulmaktadır. Türkiye Cumhuriyeti'nin kuruluşuyla ya da Rusya'da Sovyet rejiminin kurulmasıyla Türkçe ve Rusçada bazı sözcüklerin kullanımdan kalkarken yenilerinin dile yerleşmesi bu tür dilsel olaylara birer örnektir.

Özolguların mekân ve zaman bakımından ilişkisi, yukarıda anlatılan nesne-zaman ilişkisinden ayrılamaz. Vlahov ve Florin'e göre birçok özolgu tarihsel planda milli aidiyetleri ile sıkı sıkıya bağlıdır. Yani yukarıda tarihsel özolgu haline gelmiş olan sözcükler aynı zamanda milli özolgulardır. Bunların istisnası nadiren milli köklerinden kopan Eski Roma ve Antik Yunan'a ait özolgular olabilirler (Vlahov \& Florin, 1980, s. 68). Çalışmada konuyla ilgili verilen örnekleri Türkçemize uyarlarsak, örneğin örgin, divan, cülus, kapıkulu sözcükleri Osmanlı kültür ve medeniyetine ait özolgular iken cumhuriyetin kurulmasıyla yeni kurum ve kuruluşlar teşkil edilerek bunlar tarihi özolgular haline gelirler. Ancak her iki dönemin özolguları da milli özolgulardır ve milli aidiyetleri göz ardı edilemez.

Diğer bir konu, yabancı özolguların dile girmesi, benimsenmesi konusudur. Toplumlar arası karşılıklı ilişkilere bağlı olarak diller arası sözcük alışverişi gerçekleşir. Bir millete has özolgular da aynı şekilde başka toplumlarca benimsenebilir. Vlahov ve Florin, bu geçişlerin bazı dönemlerde hız kazandığını ifade ederler. Bu durum toplumsal hayatta ciddi değişimlere sebep olan dönemlerde gözlemlenir. Vlahov ve Florin Rusça için hızlı geçişlerin olduğu belli başlı dönemleri şu şekilde sıralar: 1. Hristiyanlığın kabulü, 2. Batı'dan terim ve özolguların dalga dalga Rus diline dâhil olduğu I. Petro dönemi, 3. Ekim devrimi; birçok ekonomik ve politik özolgu ve terimin dile girdiği dönem, 4 . Sovyetler Birliği dönemi; Sovyet çok dilli halklarının yaşamsal ve başka etnografik özolgularının ve bunun yanı sıra Batı Avrupa özolgu ve terimlerinin akını (Vlahov \& Florin, 1980, s. 69). Her dil için söz konusu dönemlerden bahsedilebilir ve örnekler çoğaltılabilir.

Bir dile özolguların yerleşmesinde en temel yollardan birinin edebi metinler olması konusu başlı başına bir inceleme konusudur. Edebi metinler bilim, sanat, teknoloji metinlerinin yanı sıra özolguların bir dile yerleşmesinde etkili olan en önemli sözlü ve yazılı dil unsurlarıdır. Vlahov ve Florin konuyla ilgili olarak Ukrayna asıllı yazar N. V. Gogol ve Kafkasya aşığı M. Yu. Lermontov örneklerini verir (1980, s. 70). İlki kendi topraklarına ait özolguları eserleri aracılığıyla Rus diline katarken Lermontov, çok sevdiği Kafkasya ve Kafkas halklarının yaşamına ait özolguları eserleri aracılığıyla Rus halkına tanıtmıştır.

Özolguların zamanla ilişkisiyle ilgili son sorun özolguların yabancı bir dile yerleşmesi sorunudur. Vlahov ve Florin özolguların bir dile yerleşmesinin zaman sorunu olduğunu belirtirler. Yabancı dile yerleşmesi ya da henüz yerleşmemesi bakımından özolgular tanıdık ve tanıdık olmayanlar olarak ikiye ayrılırlar. Tanıdık olanlar dile iyice yerleştiklerinden sözlüklerde yer alabilirler. Diğer yandan djungli (jungle), dolar ya da kimono gibi çok tanıdık olan özolguların yanı sıra tanıdıklık derecesi çok değişik birçok özolgu da sözlüklerde yer alabilir. Vlahov ve Florin, özolguların sözlüklerde yer bulması 
konusunun leksikografinin henüz tam anlamıyla mükemmel olmadığı için sorun olmaya devam ettiğini belirtirler. Zira halk arasında çok bilindik bir özolgu henüz sözlüklere girememişken daha az tanınan bir özolgu sözlükte yer bulabilmektedir (Vlahov \& Florin, 1980, s. 77). Özolguların ortaya çıktığı toplumlardan farklı toplumlarda da yaşaması bir gerçektir. Kültürlerarası ilişkilerde dil unsurlarının bu şekilde toplumdan topluma nakli olayı doğaldır. Ancak yine bu özolgular doğdukları toprakların malı olarak kalırlar.

\section{4. Özolguların Çevirisi}

Özolguların belirli bir dile ve kültüre has sözcük ve olgular olduğunu belirtmiştik. Bu sözcük ve olgular başka dil ve kültürlerde bulunmamaktadır. Örneğin 2010 yılı FiFA Dünya Kupası olmasaydı Güney Afrika'ya özgü bir çalgı olan vuvuzeladan haberimiz olmayabilirdi. Özolguların çevirisinde ilk sorun bu sözcüklerin çeviri yapılan dilde olmamalarıdır. Diğer yandan özolgular diğer sözcükler gibi, bazen daha da fazla, yan anlamlara sahiptirler. Örneğin yeniçeri sadece bir askeri birliğin adı değil, yerine göre kahraman, yerine göre de cülus bahşişini beğenmeyip kazan kaldıran bir asi olabilmektedir. Özolguların çevirisi sırasında çevirmen çok değişik yöntemler izlemek zorunda kalabilir. Zira özolguların taşıdığı yan anlamlar bu tür sözcüklerin çevirisini olanaksız kılan en önemli nedendir denilebilir.

Özolgunun bulunduğu metne, metindeki yerine, hedef kitleye vb. birçok etkene bağlı olarak çevirmenler bu sözcüklerin çevirisinde çok çeşitli yöntemler kullanmalıdır. Diğer yandan özolguların çevirisinde, bu sözcüklerin özellikleri nedeniyle, temelde iki yöntem vardır. Vlahov ve Florin'e göre bu yöntemler transkripsiyon ve çeviridir. Yabancı dilin kendine özgülüğünü ve kendi dilinin normlarını korumak formülü çerçevesinde çeviri, yabancı olanı maksimum seviyede kendi malı yapmak, transkripsiyon ise yabancı olanı kendi araçlarınla korumaktır (Vlahov \& Florin, 1980, s. 87).

Özolguların çevirisinde birinci yöntem dediğimiz transkripsiyon, kaynak dildeki özolguyu hedef dile, hedef dilin yazı grafik araçları ile orijinalin fonetik özelliklerine maksimum seviyede yaklaşarak aktarmaktır (Vlahov \& Florin, 1980, s. 87). Bu yönteme Türkçe ve Rusça arasındaki çevirilerde en çok Rusça şahıs adları ve yer adları ile Sovyet, kolhoz, komsomol gibi Sovyet dönemi yaşamını, toplumsal hayatını, ekonomisini ve politikasını yansıtan sözcüklerin aktarılmasında rastlanmaktadır. Vlahov ve Florin, söz konusu yönteme örnek olarak Almanca Morgen (Alman alan ölçü birimi) ve Türkçeye de aynen geçen Fransızca taverne (taverna) sözcüklerini sunarlar. Ayrıca transkripsiyon yönteminin seçimine çok dikkat edilmesi gerektiğine, çeviri ve transkripsiyon arasındaki olası yanlış tercihin okuyucuyu zor duruma düşüreceğine de vurgu yaparlar (Vlahov \& Florin, 1980, s. 87). Ünlü Rus yazar Nikolay Leskov'un Mtsenskli Lady Macbeth adlı eserinin çevirisinde çevirmen eski Rus ağırlık ölçüleri pud (16.58 kg), funt (409.5 gr) (Leskov, 2016, ss. 14-15) ile uzunluk ölçüsü versta (1.06 km) (Leskov, 2016, s. 24) sözcüklerini transkript etmiş ve dipnot olarak sayfa altında açıklamasını yapmıştır. Bizce bu yöntem uygun olup milli renklerin çeviriye yansıtılması açısından başarılıdır.

Özolguların çevirisi açısından incelediğimiz Oğuz Tansel'in Al'lı ile Fırfırı adlı eserinin Rusçaya çevirisinde transkript yöntemine başvurulduğunu gözlemlemekteyiz. Üç Peri Kızı adlı masalın çevirisinde geçen kahramanlardan Keloğlan adı (Keloglan) aynen 
bırakılmıştır. Ancak Keloğlan'ın masalda sahneye çıktığı ilk yerde şahıs ismi olarak değil sıfat tamlaması şeklinde verilmiş (kel+oğlan), böylelikle ilerleyen bölümlerde geçen Keloğlan isminin sözcük anlamı ve yan anlamları olabildiğince aktarılmaya çalışılmıştır:

"Ülkenin Birinde kimsesiz bir Keloğlan vardı" (Tansel, 2017, s. 25).

«В одной стране жил одинокий плешивый парень» (Tansel, 2018, s. 11).

Çevirinin bundan sonraki Keloğlan ismi, diğer masallar da dahil olmak üzere, transkripsiyon şeklinde verilmiştir:

“Bunu dinledikten sonra esenleşip ayrıldı Keloğlan” (Tansel, 2017, s. 26).

«Выслушав это, Кельоглан попращался пекарем и ушёл» (Tansel, 2018, s. 11).

Çevirinin bazı yerlerinde ise kel sıfatı Keloğlan'ı niteler şekilde adlaşmış sıfat olarak verilmiştir.

Transkripsiyon yoluyla aktarılan diğer özolgu ise padişahtır. Keloğlan'ın aksine padişah, Rusya'da iyi bilindiğinden herhangi bir açıklama yapılmaksızın çeviride yer almaktadır:

"Zaman zaman içinde, mavi vaktın birinde, bir padışahın bi'tecik kızı varmış" (Tansel, 2017, s. 33).

«В давние времена, когда время было голубым, у одного падишаха была единственная дочь» (Tansel, 2018, s. 14).

Padişah sözcüğü V. Dal'in ünlü sözlüğünün (Yaşayan Büyük Rus Dilinin Açıklamalı Sözlüğü - Talokovıy slovar jivogo velikorusskogo yazıka) 1882 yılına ait baskısında yer almazken, yine ünlü Rus sözlükçü Ojegov'un sözlüğünde madde başı olarak yer alır. Sözcüğün açıklaması şöyledir: Bazı Yakın Doğu ve Uzak Doğu ülkelerinde monarşi unvanı (örn. Eski Türk sultanlarının), aynı zamanda bu unvanı taşıyan kişi (Ojegov \& Şvedova, 2006, s. 488).

Bir diğer transkripsiyon örneği ise Nazlı Kız özel ismidir. Çeviride Nazlı Kız olarak verilen ismin aslı Naz Kız'dır. Ancak çevirmen bu ismi kendine göre nazlı kız diye transkript yoluyla aktarmaktadır:

“Oranın vezirinin çok güzel bir kızı varmış. Adı Naz Kız’mış” (Tansel, 2017, s. 89).

«У визиря той страны была очень красивая дочь, а звали её Назлы Кыз» (Tansel 2018, s. 31).

Transkripsiyon yönteminin uygun olmadığı durumlarda özolgular çeviri yöntemiyle aktarılırlar. Çevirinin birden fazla yolu vardır. Bunlardan ilki yeni sözcük türetmektir. Bazen dile yeni giren özolguların yeni sözcük türetme yoluyla aktarılması, kaynak dildeki sözcüğün milli özelliklerini korumada en iyi yöntem olabilmektedir. Vlahov ve Florin'e göre yeni sözcük (neologism) türetmenin ilk yolu ödünçleme ya da yarı ödünçlemedir (calque-калка). Ödünçleme, sözcük ya da sözcük grubunun sözcüğü sözcüğüne (genellikle parça parça) alıntılanmasıdır (Vlahov \& Florin, 1980, s. 88). Ödünçlemeye örnek olarak Türkçemize de İngilizceden geçen skyscraper (gökdelen) 
sözcüğünün verilebileceğini düşünüyoruz. Türkçede sky yani gök sözcüğü ödünçleme yoluyla aynen kalmış, bileşik sözcüğü oluşturan ikinci sözcük scraper ise uyarlanmıştır. Rusçada ise her iki kısımda da birebir ödünçleme yoluna gidilmiştir (neboskryob). Biz incelediğimiz Al'lı ile Fırfırı adlı eserde bu tür ödünçlemeye rastlayamadık.

Vlahov ve Florin'e göre özolguların çevirisinde bir diğer yol özümlemedir (osvoyeniye). Özümleme, yabancı özolgunun adaptasyonu, yani kaynak dildeki sözcüğün hedef dildeki sözcüklerin biçiminin verilmesidir (Vlahov \& Florin, 1980, s. 89). İncelediğimiz eserde bir masalın kahramanlarının isimlerinin bu yolla aktarıldığını görmekteyiz. Oğuz Tansel'in eserine de adını veren masal Al'lı ile Fırfırı'dır. Al'lı, al kuşak taktığı için bu şekilde adlandırılan bir canavar, Fırfırı ise ondan kaçıp bir konağa sığındığında ismi sorulunca bu adı uyduran padişahın kızıdır. Al'lı Rusça Al şeklinde aktarılmıştır. Bu aktarım uygundur, zira al sözcüğü Rusçaya da geçmiştir. Fırfırı isminin aktarılmasında ise adaptasyon yapılarak Farfara biçiminde bir aktarım tercih edilmiştir. Rusçada dişi isimler çoğunlukla -a harfiyle bitmektedir, dolayısıyla çevirmen kızın adını aktarırken doğru bir tercih ile isme Rusça biçim vermiştir. Söz konusu tercih çeviri kitabın son kısmında her bir masal için yapılan açıklamalarda da anlatılmıştır (Tansel, 2018, s. 138).

Özolguların çevirisinde semantik söz türetmelere de başvurulmaktadır. Semantik söz türetmeler, özolgunun anlamını aktarmaya yarayan, çevirmen tarafından uydurulan sözcük ya da sözcük gruplarıdır ve ödünçlemeden farkı orijinal sözcük ile etimolojik bağının olmamasıdır (Vlahov \& Florin, 1980, s. 89). Semantik söz türetmelere çevirmenler nadiren başvururlar. Bu yöntemde amaç hedef dilde olmayan bir sözcügü, mevcut sözcükler aracılığıyla çağrışım kurdurarak aktarmaktır. İncelediğimiz eserde bu yönteme örnek olabilecek bir uygulamaya rastlamadık.

Yukarıda sayılan yöntemlerin dışında diğer bir yöntem ise yaklaşık çeviridir (priblizitelnıy perevod). Bu yöntemin de farklı uygulama yolları vardır. Özolguların çevirisinde en çok uygulanan metottur. Amaç özolgunun nesnel anlamını aktarmaktır ve bu aktarım sırasında çoğunlukla kavram, sözcük ya da söz öbeğinin milli ve kültürel özellikleri, yan anlamları kaybolmaktadır.

Tür-biçim değişimi, özolgunun yaklaşık çevirisini aktarabilmek için kullanılır. Daha kapsayıcı olan kaynak dildeki tür adı, hedef dildeki daha özel bir ad ile değiştirilir. Bu aslında çeviride genelleştirme stratejisidir. Örneğin Türkçeye aktarırken Rusça izbe (izba), köylü evi (hata), Kafkasya'da taş kulübe (saklya) ve yazlık ev (kottedj) sözcüklerini ev sözcüğü ile aktarmak bu türden bir genellemedir (Vlahov \& Florin, 1980, s. 91).

Al'ı ile Fırfırı adlı eserin Rusça çevirisinde özolguların çevirisi ile ilgili olarak tercih edilen stratejilerden biri de fonksiyonel benzerliktir. Örneğin eserde geçen çarık sözcüğü Rusçaya yine Türkçeden alıntı ayakkabı, potin anlamındaki başmak sözcüğü ile aktarılmıştır. Aynı şekilde konak sözcüğü saray (dvorets) şeklinde aktarılmıştır.

Çeviri eserde oldukça fazla sayıda özolgu tespit ettik. Sayının fazla olmasından dolayı çalışmamıza, bu çok sayıdaki özolgudan kanaatimizce dikkat çekici olanlarını burada sunarak devam etmek istiyoruz. Türk kültürünü yansıtmaları bakımından önemli olduğunu düşündüğümüz özolgulardan bir diğeri de kilim motifleridir. Kilim motifleri, 
kilimlere dokunan soyut göstergelerdir. Naile. R. Oyman'a göre “[m]otif, kültürlere ait bir değerler sistemidir. Kültürleri tanımlamak, kimlikleri ortaya çıkarmak ve geleneği korumak gibi bir işlevi de vardır. Sanat ve gündelik yaşam arasında hayati bir bağ olduğuna da işaret eder. Motifler kültürü yansıtır" (2019, s. 9). Motiflerin bu özelliği sebebiyle doğrudan Türk kültürüne ayna tuttuğunu, dünyaya bakış açısını, çevresindeki dünyayı algılayışını çeşitli nesnelerin üzerine yansıttığını söyleyebiliriz. Söz konusu desenlerin dokumacılıkta kullanılan türlü türlü isimleri olduğunu Oğuz Tansel'in eserinde onun şiirsel anlatımıyla görmekteyiz:

"Kilim; temmuz göklerinden kesilmiş, yıldız ışıklı, türlü boyalarla nakış nakıştı: Karagündüzlü, benlikara, çakmaklı, eliböğründe, dallıayak, günlüorta, parmaklı, kocaoya, aylıgülizar, seviçengeli, toramanlı, kurtizi adındaki bütün örnekler kilimde konuşuyordu" (2017, s. 27).

Çeviride tüm bu motiflerin aktarılması mümkün değildir. Ancak tasvir edilebilir ki bunun için de sayfalar dolusu yazmak gerekecektir. Çevirmen bu yüzden benzetmelerden yararlanmış, motifleri ise geometrik şekillerle açıklama yoluna gitmiştir:

“Ковер как будто был соткан из июльского неба, на нем горели звезды. Он был вышит многоцветными узорами. Необычные мотивы оживали на нём. Древние таинственные знаки проступали на ковре: ромбы, квадраты, треугольники, круги, многоугольные фигуры со спиралевидными завитками" (Tansel, 2018, s. 12). İtalik yazıyla belirttiğimiz kısımda, Halı renkli bezeklerle dikilmişti. Üzerinde sıra dışı motifler canlanıyordu. Halının üzerinde kadim, gizemli işaretler görünüyordu: eşkenar dörtgenler, kareler, üçgenler, daireler, spiral kıvrımları olan çok köşeli figürler, sözleriyle Rusçaya çevrilmiş, böylelikle kültürel özellikler aktarılamamıştır. Ortalama bir Türk okuyucunun zihninde, bu motifleri isim isim bilmese dahi, belirli bir kilim ve üzerinde motifler canlanacaktır. Çeviride amaç kaynak dildeki etkinin hedef dildeki okuyucuda da uyarılması ise, bizce bu motiflerin çevirisinde en azından bir dipnot verilmeli, bir cümleyle de olsa kilim motiflerin Türk kültüründeki yerine değinilmeliydi. Ayrıca kilim sözcüğünün halı sözcüğü ile çevrilerek tür-biçim değişimi yoluyla çeviri yapıldığını da belirtmeliyiz.

Diğer yandan Üç Peri Kızı adlı masalda geçen üzeri motiflerle dolu bu kilimin seccade olarak kullanıldığını anlıyoruz: 27).

“Onlar gelene kadar Keloğlan kilim seccadenin üzerine kuruldu” (Tansel 2017, s.

Çeviride seccade sözcüğü, uçan halı şeklinde çevrilerek kültürel özellikleri kaybolmuştur: “Пока они возвращались, плешивый сел на ковер-самолет, надел шапку-невидимку, взял посох и приказал..." (Tansel, 2018, s. 12).

Halı-kilim arasında fonksiyonel benzerlikten yararlanılarak yapılan çeviri gibi peştamal sözcüğünün çevirisinde de aynı yöntem kullanılmıştır. Eserin başında yer alan tekerleme bölümünde şu ifadeler yer alır:

“Hanımlar hamam yolunda, peşetemallarının ortası yok" (Tansel, 2017, s. 13). 
“Бабы с дырявыми полотенцами идут в баню в обед” (Tansel, 2018, s. 8).

Rusça çeviride fonksiyonel benzerlikten yararlanılmış, sözcük havlu (polotentse) olarak çevrilmiştir. Peştamal, hamamda örtünmek için kullanılan ince dokuma (Türkçe Sözlük, 2011, s. 1918) olduğundan anlam genel manada aktarılmakla birlikte sözcüğün kültürel yönü aktarılamamıştır.

Çeviride bu yaklaşıma çokça rastlanmaktadır. Tarhana sözcüğü domates çorbası (tomatnıy sup), bulgur, buğday lapası (pşeniçnaya kaşa), tandır, fırın (peç) sözcükleriyle aktarılmıştır ya da daha doğrusu eksik aktarılmıştır. Bazı sözcükler ise hiç çevrilmemiş ya da anlam olarak çevrilmiştir. Tavuğun haşlanması için tencereyi sacayağı üzerine bindiriyor (Tansel, 2017, s. 48) cümlesinde geçen sacayağı (...üç ayaklı çember veya üçgen biçiminde demir destek, sacayak. Türkçe Sözlük, 2011, s. 1998) sözcüğü çevrilmemiş eserde anlatılmak istenen anlam aktarılmıştır:

“...поставил кастрюлю на огонь и положил в неё курицу” (Tansel, 2018, s. 18) cümlesinde tavuğu ateşe koydu ifadesiyle orijinal eserde verilmek istenen anlam iletilmiştir. Diğer bir eksiltme ise bir çocuk oyunu ile ilgilidir. Arakesti ülkemizde Mersin yöresinde oynanan bir çocuk oyunudur (Alişar, 1990, ss. 10-13). Eserde oyun şöyle geçer:

"Sizler de görmüşsünüzdür. Kırlangıçlar, gökyüzü çayırlığında arakesti oynarlar" (Tansel, 2017, s. 72).

Aynı sözlerin çevirisi ise şöyledir:

"Вы, наверное, видели, как на небесных лужайках играют ласточки" (Tansel, 2018, s. 24). Çeviride arakesti oyunu verilemediği için kırlangıçlar oynaşıyorlar ifadesiyle cümle eksiltilerek aktarım yoluna gidilmiştir.

Türk masallarında sıkça karşılaşılan "Kafdağı” motifi incelediğimiz eserde Naz Kız masalında geçmektedir. Birçok kültürde gözlemlenen kutsal dağ motifinin Türk kültüründeki karşılığı olan Kafdağı (Demirci, 2001, ss. 144-145) çeviride herhangi bir açıklama yapılmadan kuru bir ifadeyle aktarılmıştır:

"Yavrum, dedi, senin baban ünlü, şanlı bir başvezirdir. Kafdağına dek sözü geçer" (Tansel, 2017, s. 96).

“Сынок, твой отец - доблестный правитель. Его приказ распространяется по всему миру" (Tansel, 2018, s. 33).

İtalik verdiğimiz yerde çevirmen "Onun emri tüm dünyaya ulaşır" ifadelerini kullanmış, Kafdağı motifinden bahsetmemiştir. Bu örnekte de açıkça görüleceği üzere özolguların aktarılması ve kültürel değerlerinin doğru bir biçimde hedef dilin okuyucusuna iletilebilmesi konusunda kanımızca çevirmenlerin en büyük yardımcıları açıklayıcı dipnotlardır. Çünkü çoğunlukla başka türlü bu kavramların ve sözcüklerin çevrilmesi pek olanaklı görülmemektedir. 


\section{Sonuç}

Türkçe ve Rusça arasındaki yüzyıllardır süren ilişkiler neticesinde birçok özolgu karşılıklı olarak bu dillere yerleşmiştir. Rusların Orta Asya'daki Türk halkları üzerinde hâkimiyet kurmaları, hem imparatorluk hem de Sovyet rejimi döneminde karşılıklı ilişkiler, ayrıca Rusya'nın ülkemizle birçok açıdan ortak kültürel özelliklere sahip coğrafyalarla olan ilişkileri, coğrafyamızdaki ülkelerle birlikte Türkçede de kullanılan birçok söz varlığının Rusçaya girmesine neden olmuştur. Örneğin vezir sözcüğü Rusçaya yerleştiği için eserin çevirisinde aynı Türkçedeki gibi Arap Vezir (Vizir Arap) olarak kalmıştır. Yine kazan sözcüğü de Rusya'da bilindiğinden çeviride değiştirilmeyerek aynen bırakılmıştır. Kültürlerarası etkileşim sonucunda Türkçe ve Rusça arasında özolgularda böylesi geçişlerin varlığı önemli olmakla birlikte bu sadece buz dağının görünen yüzüdür. Özolgular her iki dil arasında yapılan çeviride ciddi sorun olmaya devam etmektedir. Oğuz Tansel'in Al'lı ile Fırfırı adlı eserinin Rusçasını incelediğimizde hedef kültürde eşdeğerliği bulunamayan özolguların çevirisinde çoğunlukla anlamın aktarılmasıyla yetinilmek zorunda kalındığı, bu sırada kültürel özelliklerin aktarılamadığı gözlemlenmiştir. Çevirmen, bizce bazı noktalarda gerekli görülen dipnot verme ve bu sayede özolguların açıklamasını yapma uygulamasına gitmemiştir. Bunun nedeni metnin akışını bozmamak olmalıdır. Ancak çeviri metnin sonunda sonuç makalesinde masal türü hakkında genel bir anlatı, Türk edebi masalcılığı ve Oğuz Tansel'in Türk masalcılığındaki yeri, edebî mirası ve şiirselliği detaylarıyla anlatılmıştır. Yazarın anlatımındaki üslubu incelenmiş, kendisinin de bir masal aktarıcısı olarak masallara kendinden birçok katkıda bulunduğu ifade adilmiş, masallardaki yoğun bir biçimde bulunan dini ögeleri, mucizeleri daha eskileriyle, eski Türk inanışlarıyla değiştirerek neomitolojizasyon yoluna gittiğine dikkat çekilmiştir (Tansel, 2018, s. 127). Ayrıca Oğuz Tansel'in masallarındaki temel motifler ve genel olarak Türk masallarında geçen dev, peri, cadı gibi mitolojik kahramanlar da eserin sonunda ele alınmıştır. Çeviri metnin sonuna böyle bilimsel bir çalışmanın eklenmesi, Türk masalcılığının ve kültürünün Rus okuyucusuna aktarılması bakımından oldukça olumludur.

Özolguların çevirisinde çevirmenin öncelikle özolguları tanıması ve anlamlandırması gerekir. Kaynak kültürü yeterince iyi tanımayan bir çevirmenden özolguları tanıması beklenemez. Bu açıdan bakıldığında özolguların çevirisi, bir kültür aktarımı olan çeviri sırasında daha da önem kazanmaktadır. İncelediğimiz eserde de olduğu gibi çevirmenlerin özolgulara dikkat etmeleri, bunları tespit ettikten sonra uygun çeviri yöntemi üzerinde düşünmeleri kaçınılmazdır. Al'lı ile Fırfırı adlı eseri Rusçaya aktaran çevirmenin özolguların çevirisi konusunda oldukça başarılı olduğunu ifade etmeliyiz. Bunda çevirmenin Türk kültürünü yakından tanımasının ve eğitiminin kültür bilim alanında olmasının başlıca etkenler olduğunu söyleyebiliriz. Çalışmamızın, özolguların sınıflandırması ve bunların çevirisi konusunda gelecekte yapılacak kuramsal çalışmalara kaynaklık edeceğini, bu sayede söz konusu sınıflandırma ve çeviri önerilerinin geliştirilmesine katkıda bulunacağını umuyoruz. Diğer yandan incelememizin uygulama açısından çevirmenlere yol göstermesini temenni ediyoruz. Çevirmenlerin dikkatinin söz konusu sözcük ve kavramlara yoğunlaşması sayesinde çeviri 
eserlerin kültür aktarımı ve tanıtımı görevini daha da başarıyla geçekleştireceğini düşünüyoruz.

\section{Kaynakça}

Alişar, F. (1990). Mersin'in Musalı Köyünde Oynanan Çocuk Oyunları. İçel Kültürü. 4, 10, Ocak, 10 13.

Bogdanoviç, G.Yu. (2004). O nekotorıh terminah sovremennoj lingvokulturologii. Kultura narodov priçornomorya. 53, 65-69.

Demirci, K. (2001). Kafdağı. TDV İslam Ansiklopedisi. Cilt 24. İstanbul: TDV Yayınları.

Fenenko, N.A. (2007). Lingvistiçeski status termina realiya. Vestnik VGU, Seriya: Lingvistika $i$ mejkulturnaya kommunikatsiya. 2, Ç. 1.

Gültek, V. (2004). Rusça-Türkçe Sözlük. Ankara: Bilim ve Sanat Yayınları.

Karavin, H. (2016). Çeviri Kuramları Bağlamında Eşdeğerlik Kavramının İzini Sürmek. Trakya Üniversitesi Edebiyat Fakültesi Dergisi, 6(12), 125-144.

Komissarov, V. N. (1973). Slovo o perevode. Moskva: İzd. Mejdunarodnıye otnoşeniya.

Komissarov, V. N. (1990). Teoriya perevoda (Lingvistiçeskiye aspektı). Moskva: Vısşaya şkola.

Kurat, A. N. (1999). Rusya Tarihi. Ankara: Türk Tarih Kurumu.

Leskov, N. (2016). Mtsenskli Lady Macbeth. Çev. Uğur Büke. İstanbul: Dedalus Kitap.

Morsy, T. A. (2019). Newmark'ın Çeviri Yöntem Ve Stratejileri Bağlamında Teneke Romanının Arapça Çevirilerinde Yerel Kültür Unsurlarının Aktarımı Üzerine Bir İnceleme. Turkish Studies, 14(4), 2595-2624.

Mosiyenko, L. V. (2014). Kültürdilbilimde Özolguların Sınıflandırması Sorunu. Çev. E. Uğurlutan. Kültürdilbilim, Temel Kavramlar ve Sorunlar. Ankara: Gazi Kitabevi.

Ojegov, S. İ. \& Şvedova, N. Yu. (2006). Tolkovıy slovar velikogo russkogo yazıka: 80000 slov $i$ frazeologiçeskih vrajenii. Rossiiskaya akademiya nauk. İnstitut russkogo yazıka im. V.V. Vinogradova. 4-e izd. M.: OOO "A TEMP".

Oyman, N.R. (2019). Bazı Anadolu Kilim Motiflerinin Sembolik Çözümlemesi. Arış Dergisi, 14, 4-22.

Tansel, O. (2017). Al'lı ile Fırfırı. Ankara: Elips.

Tansel, O. (2018). Al i Farfara. Skazki. Per. A.M. Jerdeva. LitRes: "Samizdat".

Türkçe Sözlük. (2011). Ankara: Türk Dil Kurumu Yayınları.

Vlahov, S. \& Florin, S. (1980). Neperevodimoye v perevode. Moskva: Mejdunarodnıye otnoşeniya. 